\title{
Editorial
}

\section{Why Is There No Theory of Perestroika?}

The idea of the transition from the etatistic socialism to free-market democracy is sweeping through Central Europe and USSR and is starting to affect the entire globe: young generations everywhere are now yearning to be free from the degradation and wastefulness of command, hierarchy, alienation and non-participation.

These momentous and spontaneous strivings of the people are expressions of their need for autonomy, selfrealization and knowledge-based human completion: these strivings are exploited and artificially labeled (and also confusedly accepted in the West) as 'perestroika'. As if the half-way, half-hearted pseudodesigns of the remaining great engineers of human souls were somehow fueling these great movements. Nothing can be farther from truth.

Perestroika is the very opposite, the very negation of the spontaneity of human spirit and human action. Perestroika of the leaders-designers is starting to differ sharply and fundamentally from the truly needed perestroika of the people. One cannot declare freedom, democracy and free markets from the pulpit, they must be grown spontaneously from below.

The worst possible course of action in economics, business and management is that which is based on half measures. It is a sign of historical incompetence if there are still some who want to have it 'both ways', who are still dreaming of their third ways, mixed economies, socialisms with human masks, and similar contraptions.

It is better not to own anything at all than to own something half-way or 'as if.' It is better to follow commands than to be subject to the degrading confusion of having no say at all, but being allowed to say 'it' very loudly. Compromises belong to politics and politicians, but in economics and business one either goes one way or the other; one either knows or one does not; one cannot 'sort of' go into frozen noodles business and keep the refrigerators half-way on. To believe in 'half pregnancy' amounts to idiocy.

Theories are important. They provide for common language, shared understanding and harmonious coordination of action. Theories explain the past and frame the present, provide guidance for dealing with the novel and unprecedented, and allow forming of consistent

IOS Press

Human Systems Management 9 (1990) 1-2 and long-term foreign and internal policy.

Without theories guiding the current large scale socioeconomic experimentation and restructuring, there can only be the day-to-day trouble shooting and opportunistic 'muddling through' of the reactive empiricism we are now witnessing.

Theory-free 'muddling through' is characterized by frequent 'policy' reversals, trial-and-error problem solving, stop-and-go patterns of decision making, frequent personal habilitations and rehabilitations, extreme and 'puzzling' combinations of inaction and overreaction, politics of 'catching up' and 'staying a day ahead of the sheriff,' separation of words from action, and so forth.

There is no theory of perestroika.

Perestroika has been defined as a process of combining the achievements of scientific-technological revolution and the planned economy, to overcome the so called 'administrative socialism' and to bring into action the whole potential of Socialism [1]. Such 'definition' and its usefulness need no comment.

Can there be a theory of perestroika?

The answer is no. No theory of intrasocialistic (intrasystemic) perestroika can exist and its proponents are therefore naturally 'correct' and justified in not having one.

Theories of free market capitalism do exist, as they must, and so any intersystemic transition (not perestroika) from socialism to free markets and private ownership has to be rooted in such theories. The 'reversed transition,' deconstruction of the market economy into state or national socialism does not need any theory by definition.

Why is this so?

Free market capitalism and socialism are not two symmetric socio-economic alternatives, equally analyzable and debatable; they are not equal objects of purposeful choice, scientific analysis and institutional transfer. One is a spontaneous and self-organizing social order, an unintended result of free and unencumbered human action. The other comes from a purposeful imposition of constraints; it is a man-designed (artificial) feat of social engineering. One emerges spontaneously, over and over again, whenever economic agents become free and autonomous decision makers. No 'Great Designer' is needed. The other never emerges spontaneously and must always be designed, implemented and re-designed by social engineers.

So, in order to study, understand and affect one of 
these social systems, one has to form hypotheses, collect data, test hypotheses and submit the interventions to social consensus. In order to study, understand and affect the other social system, one only needs to create a set of coherent 'construction' rules, decrees and measures and then induce social participants into following them. Metaphorically, one is like an ecosystem, amoeba, tree or meadow, the other is like a machine, hammer and sickle, work camp or a gear box. One is understood by science, the other is the result of engineering.

For nationalizing private enterprises, fixing prices, dismantling markets and implementing command hierarchies only pseudotheories or no theories suffice. Moving in the opposite direction, from state socialism to free market economy, cannot be done by rules and decrees. One cannot simply declare or legislate a free market. Socialism results from imposing (partial or full) constraints on the free market. Free market however does not result from restructuring the constraints or even from removing them entirely. Free market is not a purposeful human construct, but a spontaneous, evolutionary and selforganizing emergent.

One cannot 'shock' free markets into their existence and one cannot declare them: they have to be 'grown.' Most importantly, one has to become a knowledgeable 'farmer' rather than a skillful engineer.

The spontaneous, evolutionary and scientific characteristics of capitalism were well known to both Bukharin and Lenin. Strangely, their useful thought is entirely ignored by their current propounders and rehabilitators, while their 'trash' is still being broadcast.

Bukharin was very clear that there is not and cannot be a political economy of socialism [2]:

Political economy is a science ... of the unorganised national economy. Only in a society where production has an anarchistic character, do laws of social life appear 'natural,' 'spontaneous' laws, independent of the will of individuals and groups, laws acting with the blind necessity of the law of gravity. Indeed, as soon as we deal with an organised national economy, all the basic 'problems' of political economy, such as price, value, profit, etc., simply disappear. Here the relations between men are no longer expressed as 'relations between things,' for here the economy is regulated not by the blind forces of the market and competition, but by the consciously carried out plan ... The end of capitalist and commodity society signifies the end of political economy.

Fernand Braudel chose to conclude the third volume of his momentous study on Civilization \& Capitalism by quoting Lenin [3]:

Read what Lenin wrote: 'Small-scale commercial production is, every moment of every day, giving birth spontaneously to capitalism and the bourgeoisie ... Whenever there is small business and freedom of trade, capitalism appears.' He is even supposed to have said: 'capitalism begins in the village market-place.

Even the classics of communism conclude that no theory of socialism can exist and that capitalism emerges spontaneously while socialism cannot. Why were the classics so sharp in their observations and analyses of capitalism and so hopelessly muddled, as their intellectual heirs obviously are, about the functioning of socialism?

That question I do not propose to answer.

Let me recall the words of a poet, the words of warning to all would be reformers, 'perestroikers', half-way politicians and their half-baked solutions. They are words of warning to all who would seemingly endlessly conduct experiments with human beings and seemingly forever treat people as mere objects of their 'macroeconomic manipulations' and grand designs.

Half measures can kill when on the brink of precipices, chafing in terror at the bit, we strain and sweat and foam because we cannot jump just halfway across.

Blind is the one who but half sees the chasm, and half recoils because he lost his way, half mutineer and half suppressor of the rebellion he has given birth to!

Semi-effective, semi-actions push the half people back to the half rear, the half satiated ones are but half hungry, and those half free - are half enslaved.

Half fearful, halfway on the rampage ... a bit of this and yet a half of that, a timid party-line espousing 'Robin Hood' half walking to semi-guillotine.

Lost is the opposition's firmness. Swashbuckling with a flimsy sword, one cannot be a half guard with the cardinal, and simultaneously half a king's musketeer.

There is no semi-fatherland, nor can we fathom semi-conscience; half freedom is the trek to jail, and saving our fatherland halfway would fail.

Yevgeny Yevtushenko

(Transl. A. Obolenski and V. Winston)

Ultimately, even human beings will be recognized as being more than just guinea pigs, monkeys, chicken or baby seals, and the grand, large-scale social experimentation with them and their lives will cease ... at last.

\section{References}

[1] A. Aganbegyan (Ed.), Perestroika 1989, Charles Scribner's Sons, New York, 1988, p. 1.

[2] N. Bukharin, Ekonomika perekhodnogo perioda, Moscow, 1920. Translation from A. Kaufman's 'The origin of the political economy of socialism,' Soviet Studies, January 1953.

[3] F. Braudel, The Perspective of the World, Harper \& Row, New York, 1984, p. 631.

Milan ZELENY 